\title{
Distillers dried grains with solubles compared with rapeseed meal in rations of dairy cows
}

\author{
K. Franke ${ }^{1}$, U. Meyer and G. Flachowsky \\ Institute of Animal Nutrition, Friedrich-Loeffler-Institute (FLI), \\ Federal Research Institute for Animal Health \\ Bundesallee 50, D-38116 Braunschweig, Germany
}

(Received 31 January 2009; revised version 20 May 2009; accepted 6 November 2009)

\begin{abstract}
The aim of the present study was to assess if similar performances of high-yielding dairy cows can be achieved with a high proportion of distillers dried grains with solubles (DDGS) consisting of $90 \%$ wheat and $10 \%$ barley compared with rapeseed oilmeal (RSM) in the diet. Of a total of 32 dairy cows, 16 were fed RSM as a protein source (16.5\% of ration), the others DDGS. Equivalent high dry matter intakes, milk yield, milk fat percentage and milk lactose percentages were observed. Milk protein percentages were lower when DDGS was given. Milk fat, protein and lactose yields nonetheless showed no significant differences when RSM or DDGS were fed. Since similar performances were reached with DDGS and RSM, the tested DDGS can replace RSM as a protein source in the feed of high-yielding dairy cows up to the tested amount of $16.5 \%$ of the ration.
\end{abstract}

KEY WORDS: dairy cows, milk yield, milk composition, dry matter intake, distillers dried grains, rapeseed meal

\section{INTRODUCTION}

With the increase in by-product availability from bioenergy manufacturing, the utilization of distillers grains (DGs) as feeds is gaining in importance. Due to their high protein and energy contents they may present an alternative to soyabean oilmeal, rapeseed oilmeal or rapeseed expellers in animal nutrition, but

\footnotetext{
${ }^{1}$ Corresponding author: e-mail: katrin.franke@fli.bund.de
} 
the feed value of DGs still varies considerably due to the utilized raw materials and differences in the production process (Spiekers et al., 2006). Normally DGs obtained from maize, wheat, barley, rye, sorghum or mixtures from wheat and barley are used in animal nutrition. Depending on their further processing, a distinction is drawn between distillers wet grains (DWG) and distillers dried grains with or without solubles (DDGS, DDG). The composition of the distillers dried grains furthermore depends on the extent of the fermentation and the drying processes, as well as on the addition of the solubles (Belyea et al., 1998; Spiehs et al., 2002). Due to these differences, DDGs feature a high variability in nutrient content and the availability of their protein (Powers et al., 1995; Schingoethe, 2006; Kleinschmit et al., 2007). It has not been sufficiently investigated if all kinds of DDGS are equally applicable to RSM, rapeseed expellers or soyabean meal in rations of high-yielding dairy cows, especially when high proportions of DDGS are used. Investigations on the nutrient value of distillers dried grains mainly originate from the USA and therefore are predominately based on maize as the raw material (Palmquist and Conrad, 1982; Van Horn et al., 1985; Powers et al., 1995; Al-Suwaiegh et al., 2002; Anderson et al., 2006; Kleinschmit et al., 2007; Janicek et al., 2008). Only a few studies exist on the equivalent applicability of DDGs from wheat or wheat and barley in dairy cow feeding (Dunkel, 2005; Spiekers et al., 2006; Urdl et al., 2006; Ettle, 2007). Due to the usually higher protein and lower fat and energy contents of wheat-based DDGS compared with DDGS from maize (Spiekers et al., 2006), the results achieved with maize DDGS cannot simply be transferred to the tested DDGS of the present trial. In contrast, DDGS from wheat or wheat/barley seem to be comparable (Spiekers et al., 2006). For DDGS from maize it is shown that it can be fed up to $15-20 \%$ of the ration to dairy cows without overfeeding protein (Mc Kinnon, 2008). For DDGS from wheat or wheat and barley, studies investigating the limits of application in highyielding dairy cows are lacking (Spiekers et al., 2006).

The aim of the present study was to evaluate if similar performances of highyielding dairy cows could be achieved with distillers dried grains with solubles (DDGS) consisting of $90 \%$ wheat and $10 \%$ barley at a proportion of $16.5 \%$ of the ration compared with rapeseed meal (RSM). The assignment of the animals to four groups was made since the original aim of the conducted study was to investigate the impact of the two different protein sources (RSM and DDGS) and two different iodine species on the milk iodine content (Franke et al., 2009). Since no impact of the applied iodine species on the performance is expected, the present paper focuses on the comparison between DDGS and RSM. The data of all 4 groups is additionally presented, however, to ascertain if differences occurred in both DDGS groups or just in one. 


\section{MATERIAL AND METHODS}

\section{Animals and diets}

The trial was carried out at the experimental station of the Institute of Animal Nutrition (FLI), Braunschweig with 32 dairy cows of the German Holstein breed in early lactation. The cows were divided into four groups of 8 animals each with regard to milk yield, number of lactations, and days in milk. Seasonal calving at the experimental station led to similar days in milk for all animals. At the beginning of the trial, the cows on average were $48 \pm 25$ days in milk (DIM) and featured an average number of lactations of $2.1 \pm 1.2$, a body weight of $582 \pm 74 \mathrm{~kg}$ and a daily milk yield of $31.3 \pm 6.3 \mathrm{~kg}$.

The cows were fed a total mixed ration (TMR) consisting of 50\% concentrate, $25 \%$ maize silage and $25 \%$ grass silage on a dry matter (DM) basis for ad libitum intake. The rations were formulated to meet or exceed the nutritional requirements of the cows stated by the German Society of Nutrition Physiology (GfE, 2001). The composition of the concentrates is shown in Table 1. Water

Table 1. Composition of concentrates [\%] in the experimental groups applying distillers dried grains with solubles (DDGS) or rapeseed meal (RSM) as protein source

\begin{tabular}{lcccc}
\hline Components & DDGS $^{2}$ iodide & DDGS $^{2}$ iodate & RSM $^{2} /$ iodide & RSM $^{2}$ iodate \\
\hline DDGS $^{2}$ & 33.0 & 33.0 & - & - \\
RSM $^{2}$ & - & - & 33.0 & 33.0 \\
Wheat & 25.0 & 25.0 & 25.0 & 25.0 \\
Maize & 25.0 & 25.0 & 25.0 & 25.0 \\
Dried sugar beet pulp & 13.5 & 13.5 & 13.5 & 13.5 \\
Calcium carbonate & 0.5 & 0.5 & 0.5 & 0.5 \\
Soyabean oil & 1.0 & 1.0 & 1.0 & 1.0 \\
Mineral feed $^{1}$ & 2.0 & 2.0 & 2.0 & 2.0 \\
\hline
\end{tabular}

${ }^{1}$ without iodine supplementation; per kg mineral feed: g: Ca 140, Na 120, P 70, Mg 40, Zn 6, Mn 5.4, Cu 1; mg: Se 40, Co 25, vit. E 1500; IU: vit. A 1000000, vit. $\mathrm{D}_{3} 100000$

${ }^{2}$ DDGS - distillers dried grains with solubles; RSM - rapeseed meal

The assignment of the animals to four groups was made since the original aim of the conducted study was to investigate the impact of RSM, DDGS, iodide and iodate on milk iodine (Franke et al., 2009)

was provided ad libitum. In two groups the cows received a ration with distillers dried grains with solubles (DDGS) as the main protein source (16.5\% of TMR), made from $90 \%$ wheat and 10\% barley. The DDGS was obtained from indirect drying of the stillage in "tubular bundle driers" at $105^{\circ} \mathrm{C}$ for about $15 \mathrm{~min}$. In the other two groups RSM with a low glucosinolate content ( $3.5 \mathrm{mmol} / \mathrm{kg} \mathrm{DM})$ was applied. One group of each protein source received iodine in the form of potassium iodide $(\mathrm{KI})$, the other group as calcium iodate anhydrous $\left(\mathrm{Ca}\left(\mathrm{IO}_{3}\right)_{2}\right)$. In 
the following text the diets are mentioned in the way they are shown in Table 1. The trial lasted 147 days. The iodine supplementation of the cows was in the range of the permitted maximum level of iodine in feed.

\section{Recorded parameters and analysis}

The individual feed intake was recorded continuously by self-feeding stations (Type RIC, Insentec, B.V., Marknesse, The Netherlands) and ear transponders. In each group, 7 self-feeding stations were available for the cows. The cows were housed in group pens according to their feeding group. The pens were equipped with a slatted floor and cubicles covered with rubber mats and straw dust. Milking took place twice a day at 5.30 in the morning and 15.30 in the afternoon. The milk yield was recorded with automatic milk counters at each milking. The body weight was automatically recorded when leaving the milking parlour twice daily.

Representative concentrate samples were taken once, and silage samples twice, a week. Silage samples were dried at $60^{\circ} \mathrm{C}$ for $72 \mathrm{~h}$. All samples were ground to pass through a sieve with $1 \mathrm{~mm}$ pore size. The crude nutrients in all feed samples were analysed according to the methods of the "Verband Deutscher Landwirtschaftlicher Untersuchungs- und Forschungsanstalten" (VDLUFA, Bassler, 1976). The determination of ADF and NDF was done according to Goering and Van Soest (1970) without the use of sodium sulphite. $\alpha$-amylase was applied due to the high starch contents in the concentrates. The total glucosinolate content of the RSM was analysed by HPLC according to the international standard DIN EN ISO 9167-1 (1995).

To ascertain the metabolizable energy (ME) and net energy for lactation (NEL), balance studies with four wethers each were carried out for both applied concentrates (differing in the protein source) and for maize- and grass silage, following the standard procedure described by the GfE (1991).

Milk samples for the analysis of fat, protein, lactose and urea contents were taken twice a week. The samples were preserved with bronopol and stored at $8^{\circ} \mathrm{C}$ until analysis. Fat, protein and lactose in milk were analysed by an infrared milk analyser (Milkoscan FT 6000 combined with a Fossomatic 5000, Foss Electric, Hillerød, Denmark). From the analysed data of morning and evening milk a weighted mean (considering the milk yields) was calculated for the percentages and yields of milk fat, -protein, -lactose, and -urea.

\section{Calculations and statistical analysis}

The concentrations of the crude nutrients, ADF and NDF of the TMR were established on a dry matter basis from the analysed concentrations in the 
concentrates, and the silages with regard to the percentage of the components of the TMR.

The utilizable crude protein $(\mathrm{uCP})$ describes the amount of protein that is available at the duodenum and consists of microbial and undegraded protein. It was calculated as follows (GfE, 2001):

$$
\begin{aligned}
& \mathrm{uCP}, \mathrm{g}=(187.7-(115.4 \times(\text { undegraded feed protein } \mathrm{g} / \text { feed crude protein, } \mathrm{g}))) \\
& \times \text { digestible organic matter, } \mathrm{kg}+1.03 \times \text { undegraded feed protein, } \mathrm{g}
\end{aligned}
$$

The undegraded feed protein (UDP) is based on data of the DLG (1997). For the calculation of digestible organic matter (DOM), ME, NEL and ruminal nitrogen balance (RNB) as well as for calculation of the uCP demand the formulas of the GfE (2001) were used. The difference between the uCP demand and the uCP intake demonstrates the protein balance of the animals. The energy balance was calculated by subtracting the daily requirement for maintenance and the energy content of milk from the daily energy intake. For the calculation of the energy content of milk, the formula of the GfE (2001) was applied.

Statistical analysis was performed using the SAS-software package (version 9.1, SAS Institute. Cary, NC). The experimental unit was the animal during the whole study. All parameters were tested for normal distribution by the KolmogorovSmirnov test. All data were subjected to analysis of variance (ANOVA) according to a two-factorial design:

$$
\mathrm{y}_{\mathrm{ijk}}=\mu+\mathrm{a}_{\mathrm{i}}+\mathrm{b}_{\mathrm{j}}+\mathrm{a} \times \mathrm{b}_{(\mathrm{ij})}+\mathrm{e}_{\mathrm{ijk}}
$$

where: $y_{i j}-k^{\text {th }}$ observation related to the "protein source" $i$ and the "iodine species" $j ; \mu$ - overall mean; $a_{i}$ - effect of the "protein source" (DDGS or RSM); $b_{j}$ - effect of the "iodine species" (iodide or iodate); $(a \times b)_{i j}$ - interactions between "protein source" and "iodine species" and $\mathrm{e}_{\mathrm{ijk}}$ - error term.

Thus the model included the "protein source", the "iodine species" and the interaction for "protein source" by "iodine species". Differences were considered to be significant at $\mathrm{P}<0.05$.

\section{RESULTS}

Feed composition. The used protein sources, DDGS and RSM, showed similar contents of crude protein (Table 2). DDGS provided $37.3 \%$ of the total crude protein of the ration and RSM, 37.9\% (Table 3). DDGS featured slightly higher concentrations of crude fat and NDF, while ADF was slightly lower than in RSM (Table 2). 
Table 2. Analysis of composition of the applied distillers dried grains with solubles (DDGS) and the rapeseed meal (RSM)

\begin{tabular}{lcc}
\hline Item & DDGS $^{1}$ & RSM $^{1}$ \\
\hline Dry matter, g/kg & 923 & 898 \\
Crude nutrients, g/kg DM & & \\
$\quad$ crude ash & 58 & 75 \\
crude protein & 367 & 369 \\
crude fat & 62 & 52 \\
ADF & 159 & 208 \\
NDF & 496 & 408 \\
\hline
\end{tabular}

${ }^{1}$ DDGS - distillers dried grains with solubles; RSM - rapeseed meal

Table 3. Analysis of composition of the total mixed ration (TMR)

\begin{tabular}{|c|c|c|c|c|}
\hline Item & DDGS$^{1} /$ iodide & DDGS $^{1} /$ iodate & $\mathrm{RSM}^{1} /$ iodide & $\mathrm{RSM}^{1} /$ iodate \\
\hline Dry matter, $\mathrm{g} / \mathrm{kg}$ & 618 & 618 & 611 & 612 \\
\hline \multicolumn{5}{|l|}{ Crude nutrients, g/kg DM } \\
\hline crude ash & 63 & 63 & 67 & 67 \\
\hline crude protein & 164 & 164 & 162 & 162 \\
\hline$\%$ protein from by-product & 37.3 & 37.3 & 37.9 & 37.9 \\
\hline crude fat & 42 & 42 & 37 & 38 \\
\hline $\mathrm{ADF}$ & 179 & 181 & 187 & 186 \\
\hline $\mathrm{NDF}$ & 353 & 358 & 353 & 355 \\
\hline $\begin{array}{l}\text { Glucosinolate content mmol/ } \\
\text { kg DM }\end{array}$ & n.d. & n.d. & 0.58 & 0.58 \\
\hline \multicolumn{5}{|l|}{ Energy, $M J / k g ~ D M$} \\
\hline $\mathrm{ME}$ & 11.5 & 11.5 & 11.3 & 11.3 \\
\hline NEL & 7.03 & 7.03 & 6.92 & 6.92 \\
\hline
\end{tabular}

n.d. not detected; ${ }^{1}$ DDGS - distillers dried grains with solubles; RSM - rapeseed meal

The assignment of the animals to four groups was made since the original aim of the conducted study was to investigate the impact of RSM, DDGS, iodide and iodate on milk iodine (Franke et al., 2009)

Similarly to the main protein sources, the total mixed rations (TMR) contained slightly more crude fat and less ADF when DDGS was used, as compared with RSM (Table 3), but NDF was similar in all rations. As a result of the higher fat concentration, the diets with DDGS had marginally higher ME and NEL contents.

The GSL concentration of the TMRs with RSM amounted to $0.58 \mathrm{mmol} / \mathrm{kg} \mathrm{DM}$ resulting in mean daily glucosinolate intakes in the RSM groups of $13.2 \mathrm{mmol} / \mathrm{d}$ in the group with iodide and $12.3 \mathrm{mmol} / \mathrm{d}$ in that with iodate.

Body weight. Means and standard deviations of the body weight are shown in Table 4. No significant impact of either the protein source or iodine species on body weight and no interaction was observed as well. During the entire trial 
the cows of the DDGS/iodate group showed a slightly but not significantly lower body weight than the other groups, which was already existent at the beginning of the trial.

Dry matter intake (DMI). The averaged DMI of the cows amounted to $21.3 \pm 2.5 \mathrm{~kg} / \mathrm{d}$. The DMI when DDGS was used was not significantly different from the DMI with RSM (Table 4). Numerically higher DMIs were observed in the RSM/iodide group, being up to $2.2 \mathrm{~kg} / \mathrm{d}$ higher than in the other groups. Although the other three groups showed similar DMIs, this fact caused slightly higher means for RSM compared with DDGS.

Energy and protein supply. Similar results were observed for ME, NEL and XP intakes, showing no significant differences but slightly lower values when DDGS was used due to higher feed intakes in the RSM/iodide group (Table 4). The energy balance was positive in all experimental groups $(5.4,16.5,17.7$ and 9.9 MJ NEL/d for DDGS/iodide, DDGS/iodate, RSM/iodide, and RSM/iodate, respectively).

The daily intake of protein that is not degraded in the rumen (UDP) was slightly higher in the DDGS feeding (Table 4) but also did not achieve significance.

The average RNB was positive in all experimental groups $(6.7,6.4,13.5$ and $12.8 \mathrm{~g} / \mathrm{d}$ in the DDGS/iodide, DDGS/iodate, RSM/iodide, and RSM/iodate groups, respectively).

The calculated daily intake of available protein at the duodenum (uCP, consisting of microbial protein and UDP) showed no significant differences between DDGS and RSM. Although the UDP was slightly higher when DDGS was given, numerically lower $\mathrm{uCP}$ values were observed when DDGS was used, resulting from a numerically but not significantly higher $\mathrm{uCP}$ in the $\mathrm{RSM}$ /iodide group while the other groups showed similar values. The protein balance (calculated from the daily uCP intake and demand) was positive for all experimental groups (248, 462,469 and $231 \mathrm{~g} / \mathrm{d}$ for DDGS/iodide, DDGS/iodate, RSM/iodide, and $\mathrm{RSM}$ /iodate, respectively).

Milkyield. The average milk yield was $34.2 \pm 5.7 \mathrm{~kg} / \mathrm{d}$. No significant differences in milk yield were found between the DDGS and RSM groups (Table 4). The daily milk yield was $0.9 \mathrm{~kg}$ higher on average, however, when feeding DDGS. With regard to the single group's means it becomes obvious that this fact mainly results from differences in the supplementation with iodide.

Milk composition. Milk fat percentage and milk fat yield were neither significantly influenced by the protein source nor by the iodine species and no interaction was observed, either (Table 4). Numerically lower contents were seen, however, for DDGS use; this was apparent in both DDGS groups. 


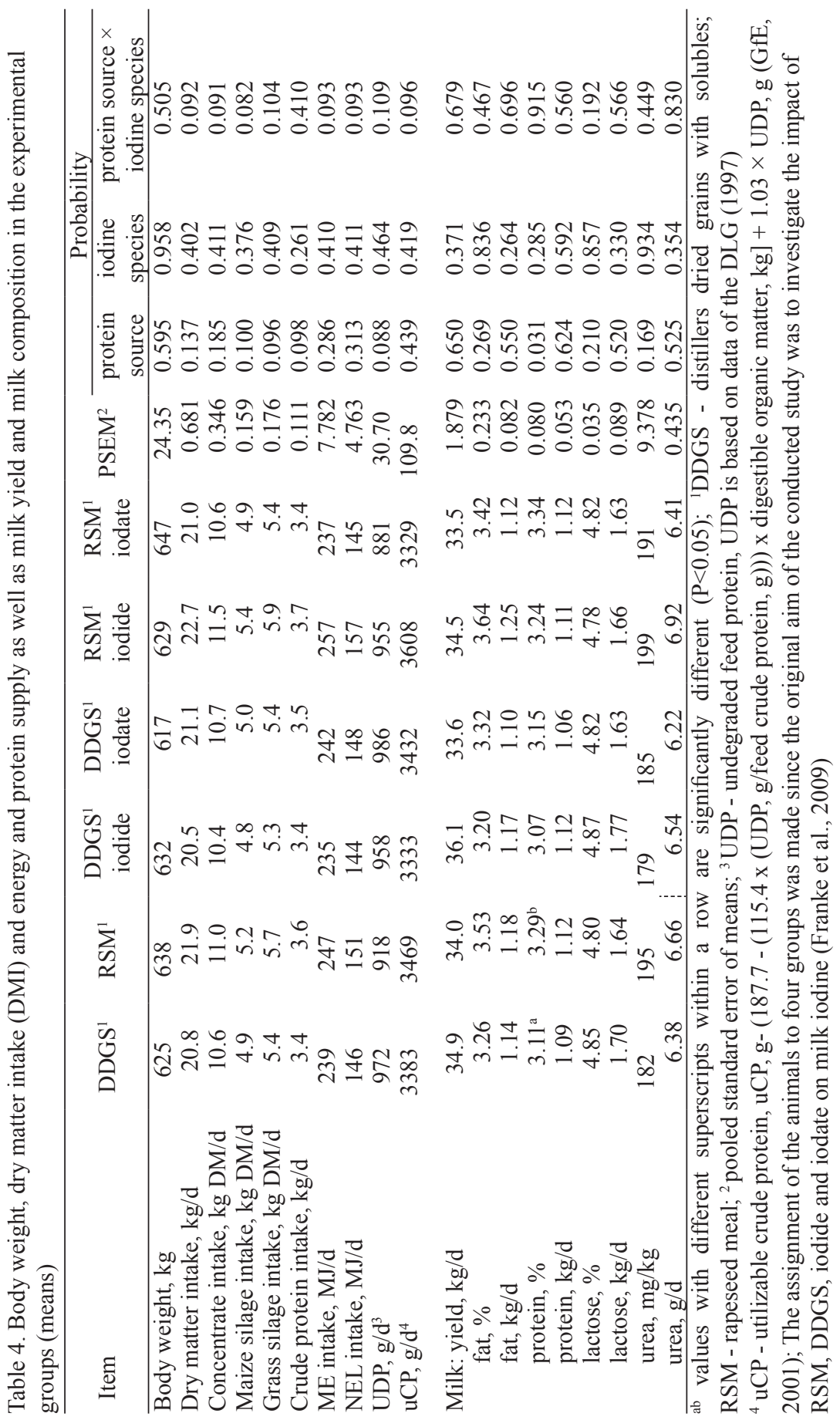


A significantly lower milk protein percentage was shown for the DDGS group (Table 4). The iodine species showed no significant impact and no interaction between both tested impact factors was observed. Considerable differences were detected for both DDGS groups (Table 4). The milk protein yield per day was slightly lower in the DDGS group, but the difference was not significant. Regarding single group means, just a numerically lower milk protein yield occurred when iodate was supplemented.

Milk lactose percentage and yield as well as milk urea content were not significantly altered by the protein source or the iodine species (Table 4).

\section{DISCUSSION}

The tested DDGS batch reflects the high NDF contents usually found in distillers grains and shows that DDGS from wheat and barley, similarly to DDGS from wheat, feature equal protein and higher fat concentrations compared with RSM (Schingoethe, 2006; Wiedner, 2008). The crude protein, crude fat, NDF, and ADF concentrations of the DDGS were in the intermediate range of previously determined values for DDGS from wheat complied by Schingoethe (2006), which varied from $30.5-44.7 \%$ for protein, $3.1-9.9 \%$ for fat, 33.4-57.0\% for NDF and $11.1-24.3 \%$ for ADF. In addition, similar crude ash, protein and fat contents were reported for DDGS from wheat and barley in Germany (Spiekers et al., 2006; Wiedner, 2008). The detected GSL levels of the TMR were far below the described tolerance level for ruminants of $1.5-4.22 \mathrm{mmol} / \mathrm{kg}$ diet (Tripathi and Mishra, 2007).

The high DMIs in the DDGS groups showed the good acceptance of the kind and amount of DDGS used. Former studies investigating the substitution of soyabean meal, a mixture of soyabean meal and rapeseed cake, RSM or rapeseed cake by DDGS from wheat also found no differences in DMI (Dunkel, 2005; Urdl et al., 2006; Ettle, 2007). No explanation could be found for the higher DMIs observed in the RSM/iodide group in the present study.

Although no significant differences were detected for the daily UDP intake, a P-value of $<0.1$ for the impact of the protein source and numerically lower values in the RSM/iodate groups indicate that only the high DMI in the RSM/ iodide group may have prevented significance. Despite the slightly higher UDP the microbes in the rumen were also sufficiently supplied with $\mathrm{N}$ when DDGS was fed, as indicated by a positive RNB.

The similar uCP intake in both DDGS groups and the RSM/iodate group at simultaneously numerically higher $\mathrm{uCP}$ intake in the RSM/iodide group show that differences mainly occur due to the numerically higher DMI and therefore 
higher intake of crude protein in the latter group (Table 4). The positive protein balance (uCP intake - uCP demand) indicates a sufficient supply of the animals with protein, but the $\mathrm{uCP}$ does not make a statement about the availability of this protein. Therefore it cannot be assessed from this parameter if heat damage of the protein of the tested DDGS had occurred during the drying process.

The present study affirms results of former studies where similar milk yields were observed with wheat DDGS in comparison with either RSM or soyabean meal (Ettle, 2007) or a mixture of soyabean meal and rapeseed press cake (Urdl et al., 2006). Dunkel (2005) detected lower milk yields when DDGS was used and suggested that overheating of the DDGS resulting in lower protein and energy availability or a lower energy content of feed may have caused this effect. The short drying at relatively low temperatures seems to have prevented heat damage of the proteins in the DDGS used in the present trial, allowing high protein availability.

In former studies with wheat DDGS, no effect of using DDGS on milk fat was observed (Dunkel, 2005; Urdl et al., 2006; Ettle, 2007). Although the difference in the present study was not significant, the results show the problem of feeding high amounts of DDGS. The increasing fat content of the diet with the rising proportion of DDGS is accompanied by a risk of milk fat depression (Kononoff and Christensen, 2007). This problem can be avoided, however, when the high fat contents are taken into consideration at formulation of the ration.

No differences in milk protein percentage were observed by Dunkel (2005), Urdl et al. (2006), and Ettle (2007). In the present study the lower milk protein percentage when DDGS was used may result mainly from slightly but not significantly higher milk yields, since no significant differences were established for the milk protein yield. Schingoethe (2006) also stated that milk protein depression due to feeding DDGS is hardly observed but may appear due to limiting protein or lysine intake or due to higher fat contents of the diet. The positive protein balance and unchanged milk yields in the present trial indicate a sufficient protein supply for the animal, but the lysine content was not determined. A slightly higher fat concentration of the DDGS compared with RSM was observed, however, and may have contributed to the lower milk protein percentages.

\section{CONCLUSIONS}

Equivalent high performances were achieved when feeding distillers dried grains with solubles (DDGS), made of $90 \%$ wheat and $10 \%$ barley, as the protein source compared with rapeseed meal (RSM). The results of this study, therefore, show that the tested DDGS can replace RSM in dairy cow rations in amounts up to $16.5 \%$ ( $37 \%$ of total protein). 


\section{REFERENCES}

Al-Suwaiegh S., Fanning K. C., Grant R. J., Milton C. T., Klopfenstein T.J., 2002. Utilization of distillers grains from the fermentation of sorghum or corn in diets for finishing beef and lactating dairy cattle. J. Anim. Sci. 80, 1105-1111

Anderson J.L., Schingoethe D.J., Kalscheur K.F., Hippen A.R., 2006. Evaluation of dried and wet distillers grains included at two concentrations in the diets of lactating dairy cows. J. Dairy Sci. 89, 3133-3142

Bassler R.E., 1976. Die chemische Untersuchung von Futtermitteln. Methodenbuch, Band 3. VDLUFA, Darmstadt

Belyea R., Eckhoff S., Wallig M., Tumbleson M., 1998. Variability in the nutritional quality of distillers solubles. Bioresource Technol. 66, 207-212

DLG, 1997. Futterwerttabellen, Wiederkäuer. DLG-Verlags-GmbH, Frankfurt am Main

Dunkel S., 2005. Fütterung von getrockneter Weizenschlempe am Milchkühen. http://www.lfl. bayern.de /ite/rind/14695/linkurl_0_4.pdf, Accessed April 30th

Ettle, T., 2007. Einsatz industriell erzeugter Proteinfuttermittel (RaPass, Schlempe) in der Milchviehfütterung. https://www.dafne.at/prod/dafne_plus_common/attachment_download/ 3d35ce2b616e77cb7ffe445d26e0c448/Endbericht_Projekt\%20100079_Proteinfuttermittel\%20 Milchvieh\%20corr.pdf, Accessed April 30th

Franke K., Meyer U., Wagner H., Flachowsky G., 2009. Influence of various iodine supplementation levels and two different iodine species on the iodine content of the milk of cows fed rapeseed meal or distillers dried grains with solubles as the protein source. J. Dairy Sci. 92, 4514-4523

GfE, 1991. Leitlinien für die Bestimmung der Verdaulichkeit von Rohnährstoffen an Wiederkäuern. J. Anim. Physiol. Anim. Nutr. 65, 229-234

GfE, 2001. Empfehlungen zur Energie- und Nährstoffaufnahme der Milchkühe und Aufzuchtrinder. DLG Verlag, Frankfurt am Main

Goering H., Van Soest P., 1970. Forage Fiber Analysis (Apparatus, Reagents, Procedure and Some Applications), Agric Handbook No 379. ARS-USDA. Washington, DC

Janicek B.N., Kononoff P.J., Gehman A.M., Doane P.H., 2008. The effect of feeding dried distillers grains plus solubles on milk production and excretion of urinary purine derivatives. J. Dairy Sci. 91, 3544-3553

Kleinschmit D.H., Anderson J.L., Schingoethe D.J., Kalscheur K.F., Hippen A.R., 2007. Ruminal and intestinal degradability of distillers grains plus solubles varies by source. J. Dairy Sci. 90 , 2909-2918

Kononoff P.J., Christensen D.A., 2007. Feeding dried distillers' grains to dairy cattle. Proceedings of the 2007 Western Nutrition Conference. Saskatoon (SK), pp. 197-205

Mc Kinnon J., 2008. Using wheat distillers in dairy rations. http://www.wcds.afns.ualberta.ca/ Proceedings/2008/Manuscripts/McKinnon.pdf, Accessed April 30th

Palmquist D.L., Conrad H.R., 1982. Utilization of distillers dried grains plus solubles by dairy-cows in early lactation. J. Dairy Sci. 65, 1729-1733

Powers W.J., Van Horn H.H., Harris Jr. B., Wilcox C.J., 1995. Effects of variable sources of distillers dried grains plus solubles on milk yield and composition. J. Dairy Sci. 78, 388-396

Schingoethe D.J., 2006. Utilization of DDGS by cattle. http://www.ddgs.umn.edu/articles-dairy/2006Schingoethe-\%20Utilization\%20of\%20DDGS\%20by\%20cattle.pdf, Accessed April 30th

Spiehs M.J., Whitney M.H., Shurson G.C., 2002. Nutrient database for distiller's dried grains with solubles produced from new ethanol plants in Minnesota and South Dakota. J. Anim. Sci. 80, $2639-2645$ 
Spiekers H., Urdl M., Preißinger W., Gruber L., 2006. Bewertung und Einsatz von Getreideschlempen beim Wiederkäuer. http://www.raumberg-gumpenstein.at/filearchive/fodok_1_2126_06_SPIEKERS_et_al_5_BOKU-Symposium_Tierernaehrung.pdf, Accessed April 30th

Tripathi M.K., Mishra A.S., 2007. Glucosinolates in animal nutrition: A review. Anim. Feed. Sci. Tech. 132, 1-27

Urdl M., Gruber L., Häusler J., Maierhofer G., Schauer A., 2006. Influence of distillers dried grains with solubles (Starprot) in dairy cow feeding. Slovak J. Anim. Sci. 39, 43-50

Van Horn H.H., Blanco O., Harris B., Beede D.K., 1985. Interaction of protein percent with caloric density and protein-source for lactating cows. J. Dairy Sci. 68, 1682-1695

Wiedner G., 2008. Bewertung von Trockenschlempe in der Fütterung landwirtschaftlicher Nutztiere. Proceedings of MOLD-Meeting, ALVA, 6, pp. 9-13 